Article

\title{
Biological Activity of the Salvia officinalis L. (Lamiaceae) Essential Oil on Varroa destructor Infested Honeybees
}

\author{
Leila Bendifallah ${ }^{1, *}$, Rachida Belguendouz ${ }^{2}$, Latifa Hamoudi ${ }^{3}$ and Karim Arab ${ }^{4}$ \\ 1 Laboratory of Soft technology, Valorization, Physical-chemistry of biological materials and Biodiversity, \\ Department of Agronomy, Faculty of Sciences, Université M'hamed Bougara, Boumerdes, \\ Avenue de l'indépendance, Boumerdes 35000, Algeria \\ 2 Laboratory of Aromatic and Medicinal Plants, Biotechnology Department, Faculty of Nature Sciences and \\ Life, University of Blida, Blida 09000, Algeria; belguendouzr@yahoo.com \\ 3 Laboratoire de Technologie Alimentaire, Faculté des Sciences de l'ingénieur, Université M'Hamed Bougara, \\ Avenue de L'indépendance, Boumerdès 35000, Algérie; Latifa.Hamoudi.1@ulaval.ca \\ 4 Laboratoire Valorisation et Conservation des Ressources Biologiques, Department of Agronomy, \\ Faculty of Sciences, Université M'hamed Bougara, Boumerdes 35000, Algeria; arabkarim3@gmail.com \\ * Correspondence: leila.bendifallah@gmail.com; Tel.: +213-555-285-705
}

Received: 1 May 2018; Accepted: 5 June 2018; Published: 6 June 2018

\begin{abstract}
The present work is conducted as part of the development and the valorization of bioactive natural substances from Algerian medicinal and aromatic spontaneous plants, a clean alternative method in biological control. For this purpose, the bio-acaricidal activity of Salvia officinalis (sage)essential oil (EO)was evaluated against the Varroa destructor, a major threat to the honey bee Apis mellifera ssp. intermissa. The aerial parts of S. officinalis L., 1753 were collected from the Chrea mountainous area in Northern Algeria. They were subjected to hydro distillation by a Clevenger apparatus type to obtain the EO, and screened for bio-acaricidal activity against Varroa destructor by the method of strips impregnated with the mixture EO and twin according to three doses. Pre-treatment results revealed infestation rates in the experimental site ranging from $3.76 \%$ to $21.22 \%$. This showed the heterogeneity of infestations in hives according to the density of bees. This constituted a difficulty in monitoring the population dynamics of this parasite. After treatment, a difference in the acaricidal effect of Sage essential oil is noticed. It gives a mortality rate of $6.09 \%$ by the dose D1: $5 \%, 2.32 \%$ by the dose D2: $15 \%$, and a low mortality rate of $0.9 \%$ by the dose D3: $20 \%$. The chemical treatment carried out by Bayvarol gives a result close to that of the essential oil of Sage $(9.97 \%)$. These results point to the fact that Sage essential oil treatments have a significant effect and good biological activity with regard to harmful species.
\end{abstract}

Keywords: Apis mellifera intermissa; bio-acaricide; Algeria

\section{Introduction}

In addition to its different products (honey, royal jelly, pollen), the honeybee plays an important role in the pollination of both cultivated and wild plant species. As a result, it actively contributes to the development and preservation of the biodiversity of ecosystems by promoting the sustainability of flowering plants. It is also considered a true bio-indicator of environmental health [1].

However, the bee is confronted with several constraints that limit its development and that can even cause its disappearance. These constraints are related to the environment (climate and the reduction of food resources), chemical agents (intoxication by phytosanitary products), apicultural practices, and biological agents (bacteria, viruses, parasites, predators). 
Among the bee diseases, Varroasisis considered one of the most widespread and dangerous diseases. It is caused by the Varroa destrucor Anderson and Trueman, 2000, mite, which parasitizes both brood and adult bees, thus causing considerable losses to the bee population. Several factors, such as the sale of queens and swarms and transhumance, have contributed to the spread of this disease worldwide [2,3].

The losses amount to some thousands of hives just for Eastern Europe [4]. In Algeria, the first varroa was reported in June 1981 on A. mellifera ssp. Intermissa at Umm-Teboul in Alkala (Annaba). Since then, this parasite has spread to the north of the country [5] and caused the considerable loss of hives. Several methods of physical (heat and fumigation), genetic (breed selection), chemical, and biological control show their efficiency on this parasite, including products like Bayvarol, Apiston, and Apivar and plant extracts such as essential oils of Eucalyptus Radiata A. Cunn, Allium sativum L., Rosmarinus officinalis L., and Origanum glandulosum Desf. [6].

Currently, there is lot of interest towards traditional medicines and herbal-based treatment all over the world. Therefore, numerous experimental and clinical studies are being undertaken on medicinal plants and there is a need for updating and integrating the findings [7].

Colin [8] has shown that many plant essential oils have an antiparasite effect, act on the behavior and/or the development of certain arthropods, and can sometimes be fatal.

More than 120 components are characterized in the essential oil prepared from aerial parts of S. officinalis. The main components of the oil include borneol, camphor, caryophyllene, cineole, elemene, humulene, ledene, pinene, and thujone [9-11]. The sage oil has a direct effect on the nervous system [12]. Camphor, thujone, and terpene ketones are considered as the most toxic compounds in S. officinalis. These compounds may induce toxic effects. According to Veličković et al. [13], bornyl acetate, camphene, camphor, humulene, limonene, and thujone are the most comment phytochemicals in the leaves. However, it should be considered that, like other herbs, the chemical composition of S. officinalis varies depending on the environmental conditions such as climate, water availability, and altitude [14].

In this work, Salvia officinalis (Lamiaceae) is chosen for its acaricidal effect on the Varroa destructor, parasite of Apis mellifera ssp. Intermissa, in comparison with Apivar, which is a commercial chemical product frequently used in Algeria. Our goal is to study the acaricidal activity of its essential oil as a biological alternative to the biopesticide usually practiced in Algeria.

\section{Results}

\subsection{Estimation of the Initial Infestation Rate in Hives by the Varroa Mite Destructor before Treatment}

The estimated global number of bees on which we conducted our study is 85,000 bees (Table 1 ). The estimated overall parasitic varroa number is 9801 , with an infestation rate of $11.53 \%$ judged to be higher than the tolerance threshold established by Robaux [15], which is 5\%. This is a strong indicator that this apiary deserves support and immediate treatment.

Table 1. Estimation of the initial infestation rate (before treatment) in the different hives and lots.

\begin{tabular}{|c|c|c|c|c|c|}
\hline Hive Number & $\begin{array}{c}\text { Number of } \\
\text { VARROA DIED } \\
\text { for } 01 \text { Months "A" }\end{array}$ & $\begin{array}{c}\text { Mean } \\
\text { Mortality/d } \\
\text { B = A/29 }\end{array}$ & $\begin{array}{c}\text { Estimated Varroa } \\
\text { Population } \\
C=B \times 90\end{array}$ & $\begin{array}{c}\text { Estimated } \\
\text { Population Bees: } \mathbf{P}\end{array}$ & $\begin{array}{c}\text { Initial } \\
\text { Infestation } \\
\text { Rate } \mathrm{T}_{\mathrm{I}} \%\end{array}$ \\
\hline Hive1 & 422 & 14.55 & 1309 & 6250 & 20.94 \\
\hline Witness batch1 & 536 & 18.48 & 1663 & 15,000 & 11.087 \\
\hline Hive 3 & 91 & 3.13 & 282 & 7500 & 3.76 \\
\hline Hive 4 & 131 & 4.51 & 406 & 8750 & 4.64 \\
\hline Hive 6 & 209 & 7.2 & 648 & 11,250 & 5.76 \\
\hline Batch3 & 438 & 15.07 & 1356 & 19,375 & 6.99 \\
\hline
\end{tabular}


Table 1. Cont.

\begin{tabular}{|c|c|c|c|c|c|}
\hline Hive Number & $\begin{array}{c}\text { Number of } \\
\text { VARROA DIED } \\
\text { for } 01 \text { Months "A" }\end{array}$ & $\begin{array}{c}\text { Mean } \\
\text { Mortality/d } \\
B=A / 29\end{array}$ & $\begin{array}{c}\text { Estimated Varroa } \\
\text { Population } \\
\mathrm{C}=\mathrm{B} \times 90\end{array}$ & $\begin{array}{c}\text { Estimated } \\
\text { Population Bees: } \mathrm{P}\end{array}$ & $\begin{array}{c}\text { Initial } \\
\text { Infestation } \\
\text { Rate } \mathrm{T}_{\mathrm{I}} \%\end{array}$ \\
\hline Hive 7 & 385 & 13.27 & 1194 & 5625 & 21.22 \\
\hline Batch4 & 818 & 28.2 & 2538 & 15,625 & 16.24 \\
\hline Hives treated per essential oil & 2014 & 69.39 & 6245 & 66,250 & 9.43 \\
\hline Hive 9 & 644 & 22.2 & 1998 & 10,625 & 18.8 \\
\hline Batch chemically treated & 1146 & 39.51 & 3556 & 18,750 & 18.97 \\
\hline global apiary (10 hives) & 3160 & 108.9 & 9801 & 85,000 & 11.53 \\
\hline
\end{tabular}

2.2. Estimation of the Infestation Rate in the Different Hives after Treatment with the Essential Oil of Sage Salvia officinalis

We note that the rate of varroa infection estimated after treatment with the essential oil of sage is 6930 individuals living at the expense of 66,250 bees (Table 2). This number is the equivalent of an infestation rate of $10.46 \%$, judged to be above the tolerance threshold established by Colin [8], which is $5 \%$. This result is directly related to the total number of bees in the apiary, which shows that dense colonies prevent the parasite from overgrowth.

Table 2. Estimation of the infestation rate in different hives and batches after inhalation treatment with sage essential oil.

\begin{tabular}{cc}
\hline Hive & $\begin{array}{c}\text { Infestation Rate after } \\
\text { tr: TI\% }\end{array}$ \\
\hline Witness batch1 & 26.4 \\
Batch2 & 6.09 \\
Batch3 & 2.32 \\
Batch4 & 0.9 \\
Hives treated/Essential oil & 10.46 \\
Chemically treated batch & 9.97 \\
\hline
\end{tabular}

The highest infection rate is that of the control with $26.4 \%$, followed by that of the batch treated with the essential oil and then that treated with the chemical (Bayvarol). This result shows the toxic effect of the oil on the parasite $(10.46 \%)$, which is more important compared to that of the chemical evaluated at $9.97 \%$.

2.2.1. Comparison between the Effect of the Different Doses of EO in the Batches 01, 02, 03, Treated with the Chemical Treatment

The comparison between the effect of the different doses of EO in the batches $01,02,03$, treated with the chemical treatment, is noted in Figure 1.

The essential oil of sage has a toxic effect on varroa, and it is higher (10.46\%) than that of chemical treatment $(9.97 \%)$. 


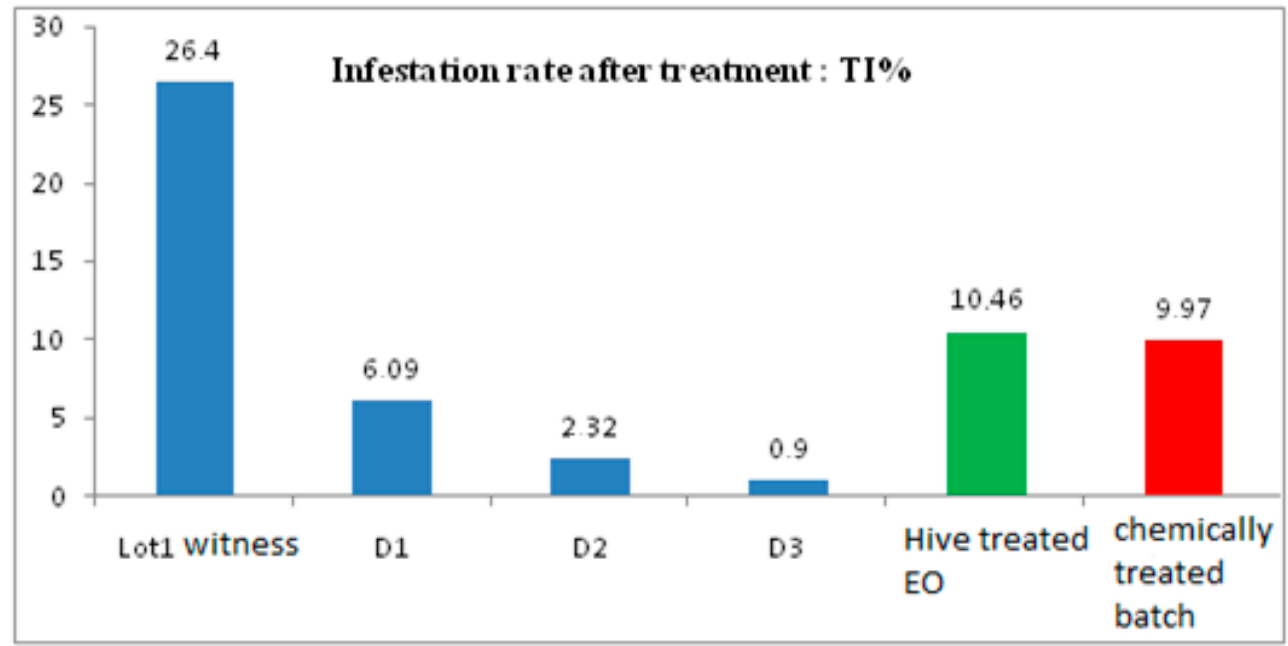

Figure 1. Infestation rate after treatment. EO: Essential Oil.

\subsubsection{Statistical Analysis of the Results: Variance Analysis}

- Number of varroa in the apiary (10 hives) before treatment

According to the analysis of the variance performed with the GLM test, the number of varroa that diedvaries marginally ( $p=0.093, p<5 \%$ ), depending on the number of bees in the hives, and does not depend on the treatment period. The most populated hives are 10 and 9 during the period of 13 November (Figure 2).

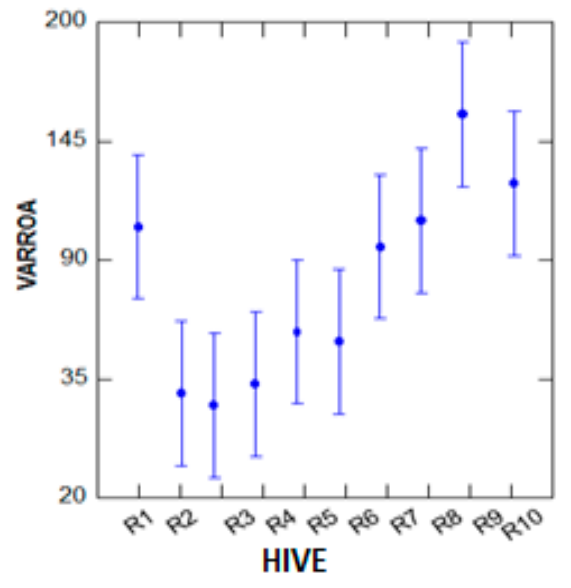

(a)

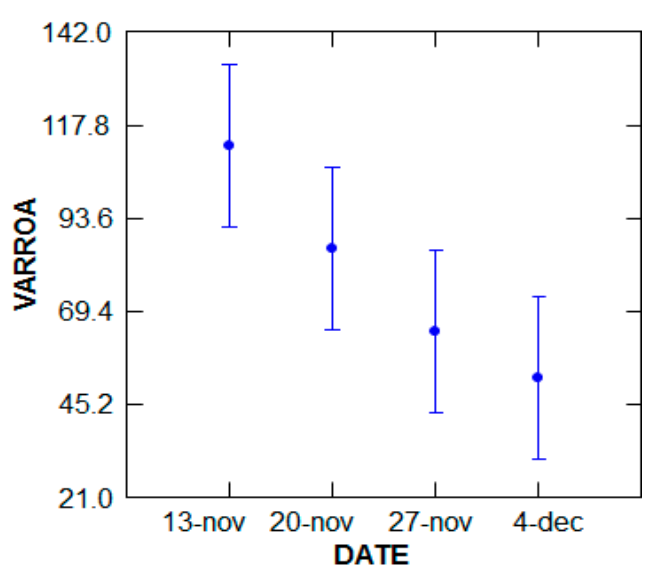

(b)

Figure 2. The variance analysis of the number of varroa that died naturally. (a) Hive; (b) Date.

- The number of varroa in the apiary after treatment

According to the variance analysis performed with the GLM test, the number of varroa that died varies in a highly significant manner $(p=0.000, p<5 \%)$, depending on the number of bees in the hives, and does not depend on the number of treatment period. The most populated hives are 01 and 07 during the period of 25 December (Figure 3). 


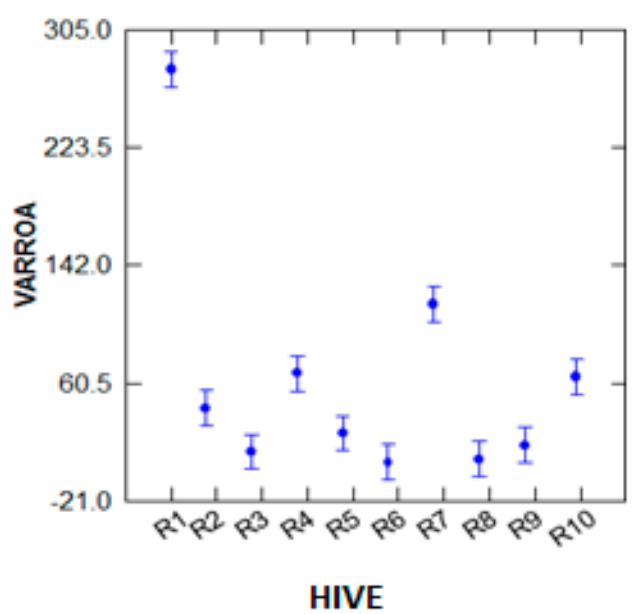

(a)

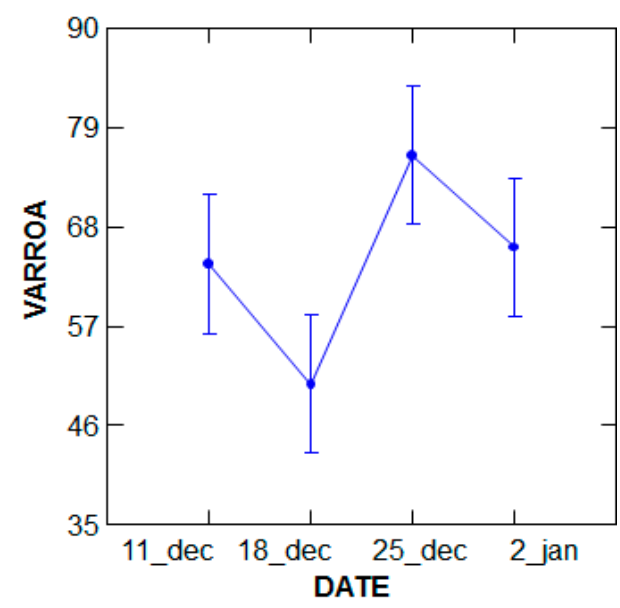

(b)

Figure 3. Analysis of the variance of the number of dead varroa by treatment. (a) Hive; (b) Date.

- Global analysis (all factors: date, hive, treatment)

According to the hive factor (colonies) and treatment:

According to the variance analysis performed with the GLM test, the number of fallen varroa varies in a highly significant manner $(p=0.000, p<5 \%)$ depending on the number of bees in the hives, without considering whether they are treated or not treated (Figure 4).

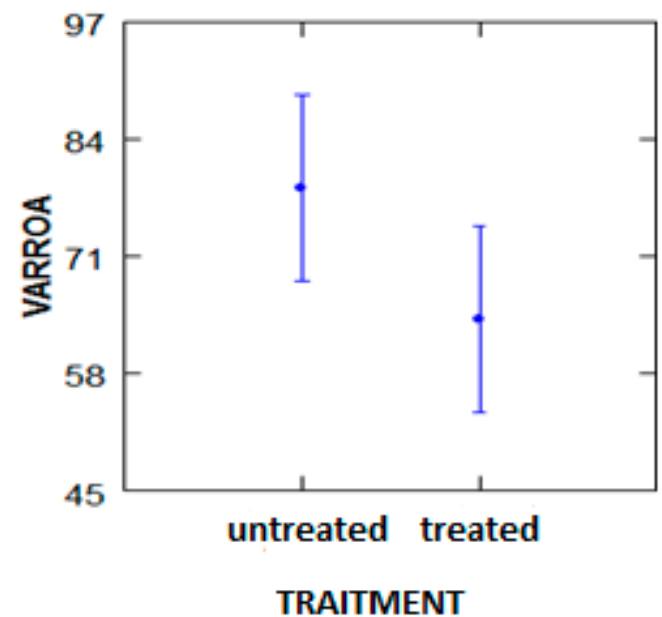

(a)

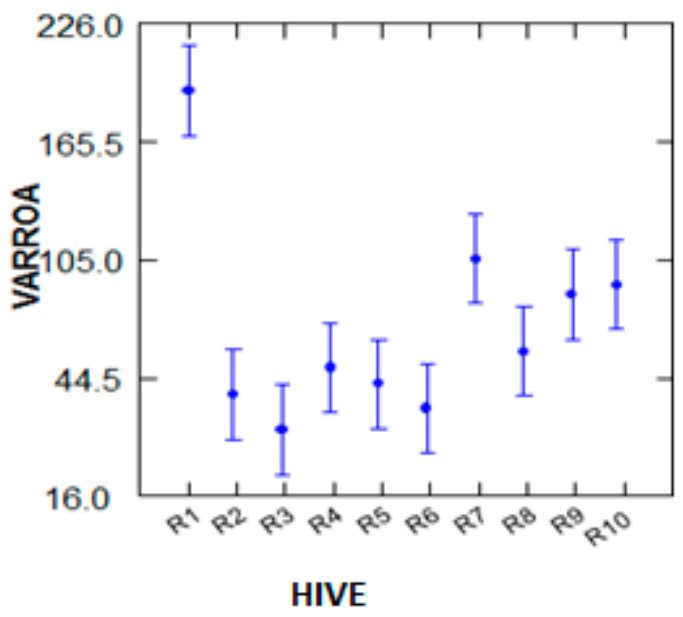

(b)

Figure 4. Analysis of the variance of the global number of dead varroa according to the hive factor and treatment. (a) Traitment; (b) Hive.

Depending on the period and treatment factor:

According to the variance analysis performed with the GLM test, the overall number of dead varroa did not depend on the treatment or the treatment period (Figure 5). 


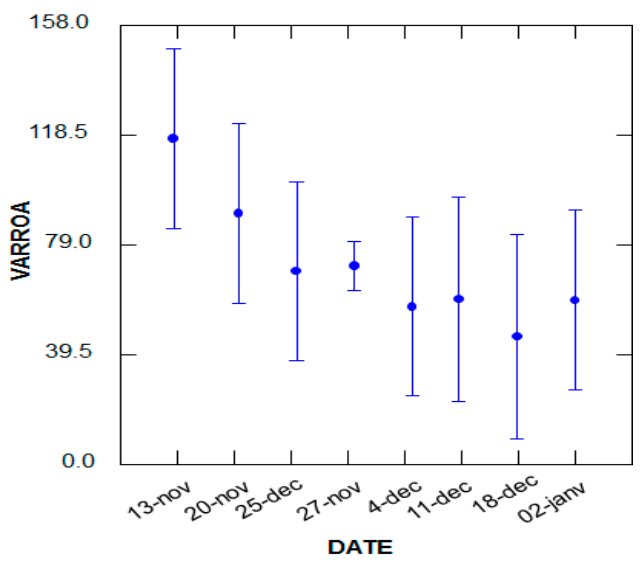

(a)

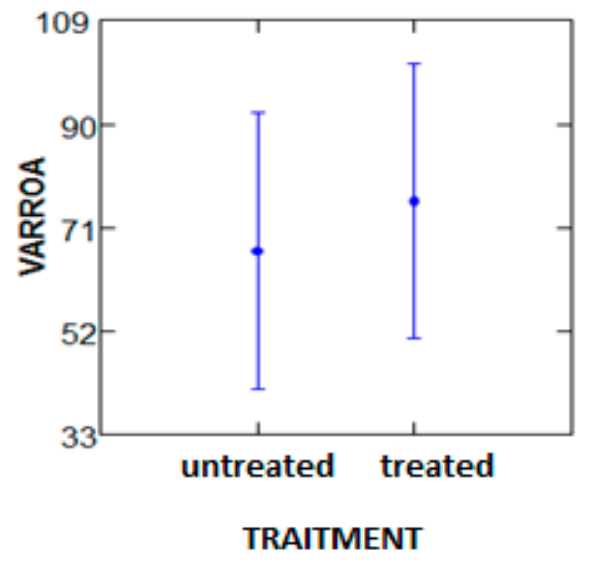

(b)

Figure 5. Analysis of the variance of the global number of dead varroa by factor period and treatment. (a) Date; (b) Traitment.

\section{Discussion}

Varroasis is a major problem and worrying when considering apiaries, and it has a proliferative capacity, thus causing the annihilation of the colonies of bees. To fight this enemy bee, beekeepers are oriented towards a non-pharmacopoeia reasoned with varroacids, giving birth to cases of resistance accentuated by quantities of residues which upset the products of the hive and human health. The orientation towards natural means such as essential oils of plants aromatics offers a valid solution because their presence is acceptable in the environment of the hive.

Currently, in Europe, several products are applied, and the most used are based on Fluvalinate and Amitraz. It should be noted that no treatment is shown to be $100 \%$ effective. Several studies have been conducted, reporting adverse effects of several acaricides on the health of bee colonies [16]. According to Pettis et al. [17], acaricide exposure enhances the susceptibility of bees to diseases and increases bee mortality from these diseases. Varroa mite management requires that acaricide treatments be varroa mite-selective, fatal to varroa mites at doses that are harmless to bees, and leave no or minimal residues in honey and wax [18].

Plants are capable of producing a wide variety of natural substances. In fact, in addition to the classic primary metabolites (carbohydrates, proteins, lipids, nucleic acids), they synthesize and accumulate perpetually secondary metabolites whose physiological function is not always obvious but which represent an immense source of molecules that can be exploited in various fields, among others, phytoprotection [19].

Currently, essential oils are beginning to generate much interest as a potential source of bioactive natural molecules. These products are being studied for their possible use as an alternative to insecticides, acaricides, bactericides, nematicides, and fungicides [20].

In this work, we study the acaricidal activity of Salvia officinalis essential oil, which has not been studied so far and comes from the Algiers region, extracted from the leaves of the plant by the hydro-distillation method. The latter allowed us to recover an essential oil yield of $0.56 \%$, which is very low and can be explained by the influence of the region (origin), the sampling period, the climatic conditions, and the method of the extraction.

Our results from the anti-mite treatment reveal an effect of the acaricidal activity of the essential oil of Salvia officinalis L. on the parasitic Varroa destructor of the honey bee Apis mellifera intermissa. This acaricidal activity varies with the dose and the period of exposure to treatment. After treatment, we found that the mortality rate presents a better result when using the dose D1: $5 \%$ and that corresponds to $21.07 \%$. This result is weak compared to that of Ghomari et al. [21], who obtained $48.7 .20 \%$ of the essential oil of Origanum vulgare, higher than that obtained by Apivar (3.13\%), and much better 
than that of Thymus vulgaris, described as being disappointing according to Giovenazzol et al. [22]. Moussaoui et al. [23] have shown that the toxicity of the Eucalyptus bioproduct occurs early.

The bee is an excellent biological indicator. It signals the state of health of the environment in which it lives. It detects the presence of phytosanitary substances, pollutants such as heavy metals, and radionuclides. It also ensures biodiversity through its role as a pollinator. The bee deserves to be protected.

\section{Materials and Methods}

\subsection{Plant Material}

The plant used in this study is the spontaneous sage Salvia officinalis (Figure 6). In our study, 30-cm apical branches were collected from Chrea, a mountainous area named Tell Atlas, near Blida, Northern Algeria (Latitude: $36^{\circ} 25^{\prime} 32^{\prime \prime} \mathrm{N}$, Longitude: $2^{\circ} 52^{\prime} 36^{\prime \prime} \mathrm{E}$, Altitude $946 \mathrm{~m}$ ), just before the appearance of the first floral bud in March 2016.This geographical location offers the plant a typically Mediterranean climate.

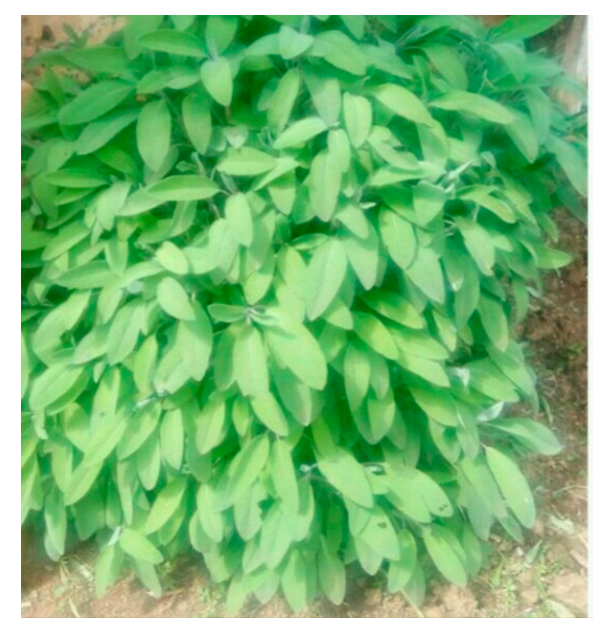

Figure 6. Salvia officinalis collected.

They were dried at room temperature and stored in paper bags according of the method of Branislava et al. [24]. The identification of this plant was confirmed according to the general herbarium package available at the High National School of Agronomy of El-Harrach (Algiers).

\subsection{Animal Material}

The V. jacobsoni O., 1904 (Arthropod: Dermanissidae or Varroidae) parasite of the domestic honeybee A. mellifera intermissa was discovered for the first time on the island Indonesian archipelago on Apis cerana (A. indica) by the entomologist Jacobson, but his study and description was made by Oudemans in 1904.

This parasite was identified according to the observations of the entomologist teachers at the High National School of Agronomy of El-Harrach—Algiers and Blida University.

Our study was conducted at the Experimental Station of the Department of Biotechnology, Faculty of Natural Sciences and Life, Blida University I. The apiary has ten hives installed in an orchard consisting of orange trees surrounded by Eucalyptus trees and those of Casuarina (Figure 7). 


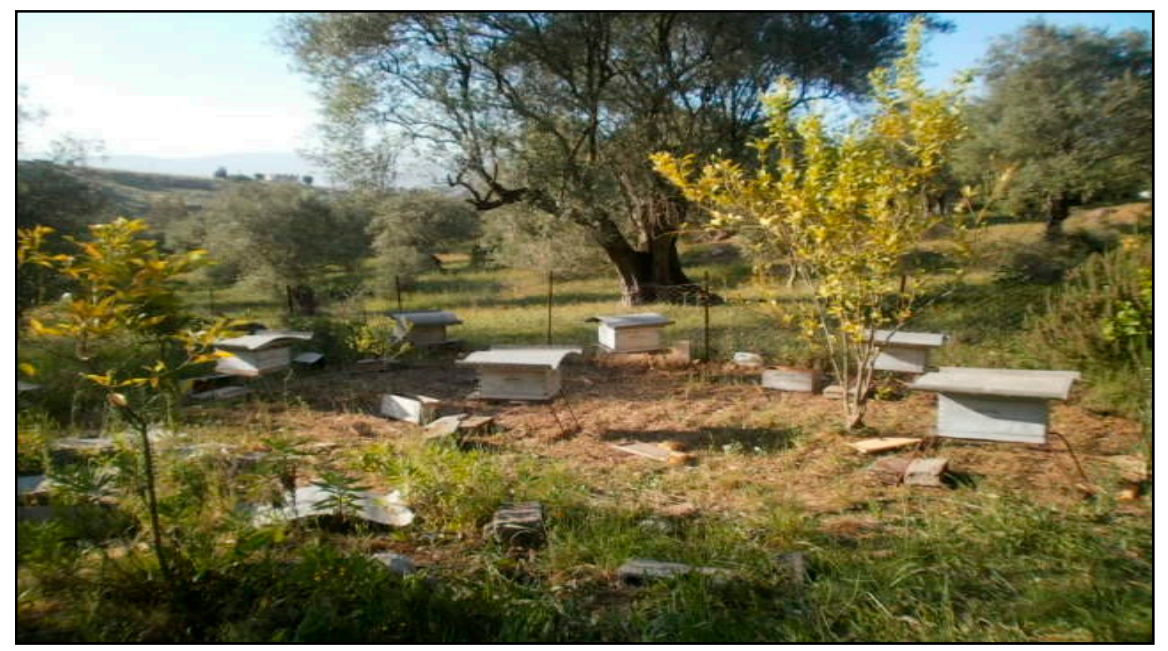

Figure 7. Location of the experimental apiary.

\subsection{Method of Extraction of Essential Oil HS from Sage}

The freshly harvested plant material was dried with a dryer at a temperature of $37^{\circ}$ for $12 \mathrm{~h}$. The aerial parts were cut into small pieces and weighed using a precision scale.

The EO was extracted by the Hydro-distillation method according to the standard procedure reported in the Sixth edition of the European Pharmacopoeia [25], using a Clevenger Type apparatus. This method involves directly immersing the plant material to be treated in a still of distilled water, which is then brought to a boil. The heterogeneous vapors are condensed on a cold surface and the essential oil separates by the difference in density [26]. After $3 \mathrm{~h}$ of boiling, the emerged oil is recovered in Eppendorf's. Distillation is repeated several times with 40g samples.

The yields of essential oils were expressed relative to the dry matter, according to the following formula:

$$
\mathrm{R} \%=(\mathrm{V} / \mathrm{M}) \times 100
$$

R: percentage of the essential oil.

V: volume obtained in essential oil.

M: weight of the dry material (g).

Preparation of the dilutions

Preparation of 03 dilutions of essential oils to be tested by diluting:

D1: $0.5 \mathrm{~mL}$ of essential oils in $100 \mathrm{~mL}$ of twin.

D2: $1.5 \mathrm{~mL}$ of essential oils in $100 \mathrm{~mL}$ of twin.

D3: $02 \mathrm{~mL}$ of essential oils in $100 \mathrm{~mL}$ of twin.

Then, we prepared strips of blotting paper $18 \mathrm{~cm}$ long and $5 \mathrm{~cm}$ wide, each impregnated with $5 \mathrm{~mL}$ of the different dilutions (D1, D2, D3).

For chemical treatment with Bayvarol, we used two strips per hive that were placed vertically between the frames (Figure 8). 


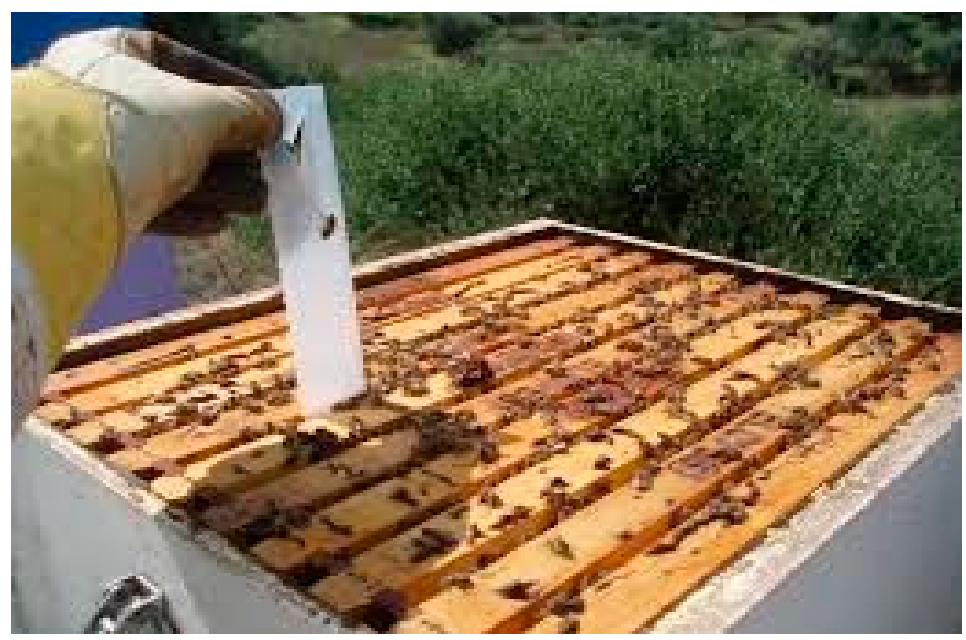

Figure 8. Treatment of colonies with Bayvarol.

\subsection{Method for Estimating the Initial Infestation Rate of Different Hives}

We applied one of the biological methods "laying nappies", using diapers on greased leaves placed on the floor of 10 hives (Figure 9).

The number of varroa was counted weekly for one month before treatment and one month after treatment.

We thus estimated, by a simple division, the mortality.

The daily mortality estimate was made by dividing the total number of Varroa by 29 days; this value was multiplied by 90 days (the maximum life span of Varroa females). This allowed us to obtain the approximate number of existing Varroa in in the colony [26].

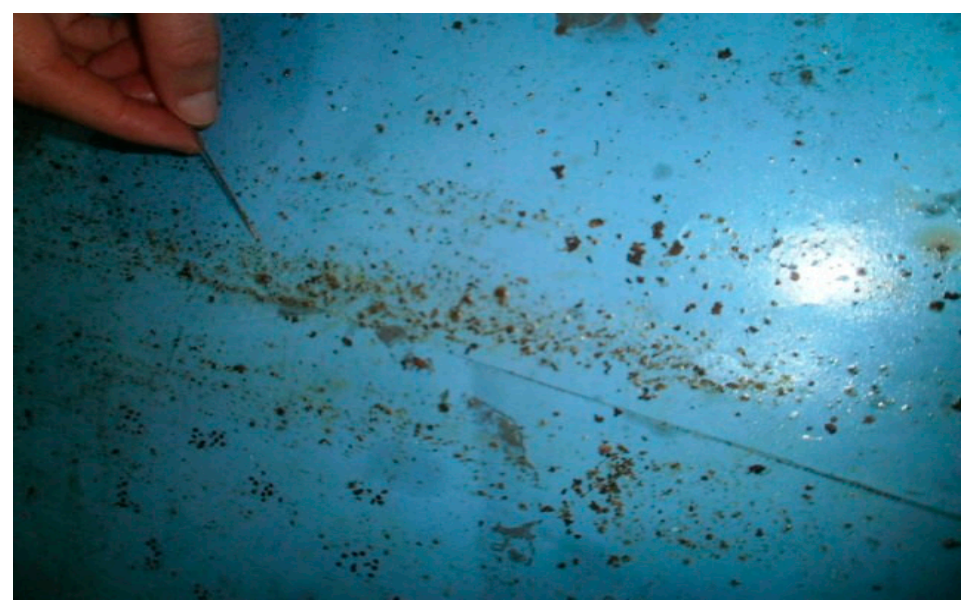

Figure 9. Counting varroa.

\subsection{Method for Estimating the Number of Bees in a Colony}

It was easy for us to estimate the number of bees in our hives, because a Langstroth frame contains 250 grams of bees and the average weight of a bee is estimated at $0.1 \mathrm{~g}$, so a frame would have 2500 bees $(250 / 0.1=2500)[27]$. 


\subsection{Method for Calculating Colony Infestation Rate}

After estimating the number of Varroa and bees in a colony, the infestation rate of this colony was estimated as follows:

$$
\mathrm{T} \cdot \mathrm{I}=\mathrm{C} / \mathrm{P}
$$

C: corresponds to the number of varroa estimated in a colony.

$\mathrm{P}$ : corresponds to the number of bees estimated in a colony [15].

\subsection{Method for Estimating the Infestation Rate of Different Hives after Treatment}

We applied the same method as previously used.

\subsection{Method for Calculating Colony Infestation Rate}

After estimating the number of Varroa that fell after the application of the treatment in the colony, the infestation rate of the colony was evaluated as follows:

$$
\mathrm{TF} \%=\mathrm{C}-\mathrm{M} / \mathrm{P}
$$

C: corresponds to the number of varroa estimated in the colony before treatment.

M: corresponds to the number of varroa that fell after the treatment.

P: corresponds to the number of bees estimated in a colony [15].

\subsection{Method for Studying the Phytotoxic Activity of Sage}

The essential oil of sage was tested for its phytotoxic activity, at different doses, to obtain the resistance of Apis mellifera bees.

In glass jars, five individuals of $A$. mellifera bees were placed on absorbent paper; each beaker contained one dose of sage essential oil (5\%, 15\%, and $20 \%$ ) and was covered with a pierced tissue to ensure the bees' breathing.

We found that the essential oil of sage is active in a toxic way against bees, as follows:

The essential oil of a $5 \%$ dose: more than $30 \mathrm{~min}$ to notice the beginning of the death of some bees. The essential oil of a $15 \%$ dose: 14.34 min to notice the death of almost all the bees.

The essential oil of a $20 \%$ dose: $6.25 \mathrm{~min}$ to notice the death of all the bees.

\section{Conclusions}

A preliminary diagnosis can be made after opening brood cells and observations of immature and adult mites present in them or by the biological method "laying nappies", which reveals, in our study, an initial infestation rate of $11.53 \%$. This rate is close to the range 10 and $20 \%$ according to Robaux [15], which means that the colony is strongly affected and requires treatment. This treatment can be done at the level of the hive with various chemicals not without danger since it destroys the mites with negative effects on: the bee, the frames and supports, and the honey. But our study is part of the simple and economical biological method to treat Varroa on the one hand, and collect and observe hive debris and mites for scientific purposes, on the other hand. Itis the method of fumigation treatment using Salvia officinalis. It is clear that treatment with Chrea sage reduced the final infestation rate to 10.46, and for the untreated lot, it was $26.4 \%$. Also, statistical analyzes showed that sage essential oil treatments have a significant effect. However, the weakness of the effectiveness of the treatment has its origin in the presence of the capped broods which "protect" the varroa inside the alveoli and thus prevent the penetration of the smoke. In other words, the varroa attached to the lower part of the body of the larva escape, unfortunately, the effects of treatment. Thus, it becomes imperative in our view for beekeepers to ensure the state of the hive before the period of the slope of the eggs to avoid any contamination. 
We conclude that the effectiveness of essential oils is related to the plant species, the dose used, and the duration of exposure.

Author Contributions: R.B. and L.H. conceived and designed the experiments; L.B. performed the experiments; K.A. analyzed the data; R.B. contributed reagents/materials/analysis tools; L.B. wrote the paper.

Funding: The founding sponsors had no role in the design of the study; in the collection, analyses, or interpretation of data; in the writing of the manuscript, and in the decision to publish the results.

Acknowledgments: This study is part of doctoral research. The authors thank all those who contributed to the achievement of this work, including the head of the experimental station of the Department of Biotechnology, Faculty of Natural Sciences and Life, Blida University I. We also thank the responsible for the herbarium at the High National School of Agronomy of El-Harrach-Algiers. The authors are grateful to Sadek Oudni, Djouhra Khitouche, and Rima Zedadra for their help. Last but not least, we thank Pr. Kamal Bechkoum for reading the manuscript and sending us helpful comments from Gloucestershire University in the UK, and the reviewers of the manuscript for their comments and suggestions.

Conflicts of Interest: The authors declare no conflict of interest.

\section{References}

1. Clement, H. L'abeille Sentinelle de L'environnement; Editions Alternatives: Paris, France, 2009.

2. Garcia-Fernandez, P.; Rodriguez, R.B.; Orantes-Bermejo, F.J. Influence du climat sur le développement de la population de Varroa jacobsoni Oud. dans des colonies d'Apis mellifera iberica (Goetze) dans le sud de l'Espagne. Apidologie 1995, 26, 371-380. [CrossRef]

3. Ellis, J.D.; Zettel Nalen, C.M. Varroa Mite, Varroa destructor Anderson and Trueman (Arachnida: Acari: Varroidae); EENY-473; IFAS Extention, University of Florida: Gainesville, FL, USA, 2010.

4. Colin, M.E. La varroase. Rev. Sci. Tech. 1982, 1, 1177-1189. [CrossRef]

5. Belaid, M.; Doumandji, S. Effet du varroa distructor sur la morphométrie allaire et sur les composants du systhème immunitaire de l'abeille ouvrière Apis mellifera intermisa. Leban. Sci. J. 2010, 11, 45-53.

6. Teffahi, M.; Belguendouz, R. Etude de L'activité Acaricide de L'origan (Origanum glandulosum) et du Romarin (Rosmarinus officinalis) Sur le Parasite (Varroa jacopsoni) de L'abeille. Master's Thesis, Blida University, Blida, Algeria, 2014.

7. Ghorbani, A.; Esmaeilizadeh, M. Pharmacological properties of Salvia officinalis and its components. J. Tradit. Complement. Med. 2017, 7, 433-440. [CrossRef] [PubMed]

8. Colin, M.E. A method for characterizing the biological activity of Essential oils against Varroa jacobsoni. In New Perspectives on Varroa A Matheson; IBRA: Cardiff, UK, 1994.

9. Badiee, P.; Nasirzadeh, A.R.; Motaffaf, M. Comparison of Salvia officinalis L. essential oil and antifungal agents against candida species. J. Pharm. Technol. Drug. Res. 2012. [CrossRef]

10. Hayouni, E.A.; Chraief, I.; Abedrabba, M. Tunisian Salvia officinalis L. and Schinusmolle L. essential oils: their chemical compositions and their preservative effects against Salmonella inoculated in minced beef meat. Int. J. Food Microbiol. 2008, 125, 242-251. [CrossRef] [PubMed]

11. Langer, R.; Mechtler, C.; Jurenitsch, J. Composition of the essential oils of commercial samples of Salvia officinalis L. and S. fruticosa Miller: A comparison of oils obtained by extraction and steam distillation. Phytochem. Anal. 1996, 7, 289-293. [CrossRef]

12. Mills, S.; Bone, K. The Essential Guide to Herbal Safety; Elsevier: Louis, MO, USA, 2005.

13. Veličković, D.T.; Ranđelović, N.V.; Ristić, M.S.; Veličković, A.S.; Šmelcerović, A.A. Chemical constituents and antimicrobial activity of the ethanol extracts obtained from the flower, leaf and stem of Salvia officinalis $\mathrm{L}$. J. Serb. Chem. Soc. 2003, 68, 17-24. [CrossRef]

14. Russo, A.; Formisano, C.; Rigano, D. Chemical composition and anticancer activity of essential oils of Mediterranean sage (Salvia officinalis L.) grown in different environmental conditions. Food Chem. Toxicol. 2013, 55, 42-47. [CrossRef] [PubMed]

15. Robaux, P. Varroa et Varroatose; Opida: Echauffour, France, 1986.

16. Pettis, J.S. A scientific note on Varroa destructor resistance to coumaphos in the United States. Apidologie 2004, 35, 91-92. [CrossRef] 
17. Pettis, J.S.; Lichtenberg, E.M.; Andree, M.; Stitzinger, J.; Rose, R.; Vanengelsdorp, D. Crop pollination exposes honey bees to pesticides which alters their susceptibility to the gut pathogen Nosema ceranae. PLoS ONE 2013, 8. [CrossRef] [PubMed]

18. Lindberg, C.M.; Melathopoulos, A.P.; Winston, M.L. Laboratory evaluation of miticides to control Varroa jacobsoni (Acari: Varroidae), a honey bee (Hymenoptera: Apidae) parasite. J. Econ. Entomol. 2000, 93, 189-198. [CrossRef] [PubMed]

19. Auger, J.; Thibout, E. Susbtances soufrées des Allium et des Crucifères et leurs potentialités phytosanitaires. In Biopesticides D'origine Végétale; Regnault-Roger, C., Philogène, B.J.R., Vincent, C., Eds.; Lavoisier, Tec \& Doc: Paris, France, 2002.

20. Yakhlef, G. Etude de L'activité Biologique des Extraits de Feuilles de Thymus vulgaris L. et Laurius nobilis L. Master's Thesis, EL Hadj Lakhdar-Batna University, Batna, Algeria, 2010.

21. Ghomari, F.N.; Kouache, B.; Arous, A.; Cherchali, S. Effet de traitement par fumigation du thym (Thymus vulgaris) sur le Varroa destructor agent de la varroase des abeilles. Nat. Technol. 2014, 10, 34-38.

22. Giovenazzol, P.; Marceau, J.; Dube, S. Essais préliminaires sur le traitement de colonies d'abeilles Apis mellifera infestées par le parasite Varroa jacobsoni en chambre d'hivernage. L'abeille 1999, 19, 5. Available online: www.agrireseau.net/apiculture/Documents/essais_traitement_acariose.pdf (accessed on 5 June 2018).

23. Moussaoui, K.; Ahmed Hedjala, O.; Zitouni, G.; Djazouli, Z. Estimation de la toxicité des d'huiles essentielles formulées de thym et d'eucalyptus et d'un produit de synthèse sur le parasite de l'abeille tellienne varroa destructor (arachnida, varroidae). Agrobiologie 2014, 4, 17-26.

24. Branislava, S.; Lakušić, C.; Mihailo, S.; Ristić, A.; Violeta, N.; Slavkovska Danilo, L.; Stojanović, C.; Dmitar, V.; Lakušić, C. Variations in essential oil yields and compositions of Salvia officinalis (Lamiaceae) at different developmental stages. Bot. Serb. 2013, 37, 127-139.

25. European Pharmacopoeia Commission. Ph. Eur. 6.0. Council of Europe; European Pharmacopoeia Commission: Strasbourg, France, 2007.

26. Bruneton, J. Pharmacognosie, Phytochimie, Plantes Médicinales, 3rd ed.; Technique et DocumentationLavoisier: Paris, France, 1999.

27. Berkani, M.L. Comparaison de Deux Types de Ruches: Dadant et Langstroth Dans les Littoral Est et Algérois. Master's Thesis, High school of Agronomy, El Harrach, Algeria, 1985. 